\title{
MANIFESTATIONS OF SYMBOLISM IN ARCHITECTURE OF POSTMODERNISM
}

\author{
Martynas MANKUS \\ Department of Architectural Fundamentals and Theory, Vilnius Gediminas Technical University, \\ Pylimo St. 29/Traku St. 1, 01132, Vilnius, Lithuania, \\ E-mail:martynas.mankus@gmail.com
}

Received 15 September 2014; accepted 12 December 2014

\begin{abstract}
The article analyses expression of symbolism in Lithuanian postmodern architecture. It discusses the concept of symbolism and transformations of its meaning in comparison to the period of modernism as well as examines its most significant aspects in semantic understanding of postmodernist architecture. The article seeks to disclose the forms of symbolism represented in Lithuanian architecture by the end of the 20th - the beginning of the 21st century. It searches for the most expressive examples of Lithuanian architecture of the given period by clarifying the character of postmodernist use of symbols. Attempts have been made to trace the expression trajectories of symbolism in contemporary architecture that have been influenced by postmodernism.
\end{abstract}

Keywords: architecture, postmodernism, symbolism, semantics of architecture.

\section{Introduction}

Expression of architecture as an object of scientific research has been analysed in different aspects and by different theoretical approaches - morphological, socio-cultural, economic and political, - but the symbolic aspect is infrequently identified as an object of analysis. While speaking about the role of symbolism in architecture of the second half of the 20th century, the influence of postmodernist phenomenon is often distinguished. Although the socio-cultural formation conditions of the phenomenon were quite different in Lithuania as compared to the Western countries, and the western influence on expression of Lithuanian architecture has been obvious. This subject is relevant because the postmodernist approach to the symbolic aspect in the second half of the 20th century was fairly different from the previously dominated neutral approach of modernism and became one of the most essential features of this trend in architecture. Symbolism aimed at suggestibility of expression, actualisation and semantisation of the cultural context. This period and expression associated with postmodernism has played an important role in the development of contemporary architecture in Lithuania.
The article aims to examine the expression of the symbolic component seeking to strengthen the artistic expression of architectural objects and increase their suggestibility in architecture affected by the postmodern phenomenon and its aesthetics. Symbols, signs, metaphors and codes are treated in the text as visual figures revealing some concept or idea and bearing traditional meanings. The article also analyses features of conception of symbolism in postmodernist architecture and aspects of its expression. These aspects supplement the field of architectural expression with cognitive, phenomenological and communicational (narrative) features.

In the theory of culture, art and architecture, the term of symbolism is often used in association with other notions, such as representation, iconicity and identity. The text refers to a general term of symbolism as encompassing all the aforementioned notions by sharpening their meaning in particular cases. Contemporary theory of architecture has appropriated and adapted a part of theoretical models of psychology, art criticism and semiotics; however in the text, some conceptions in different areas are understood and in- 
terpreted differently. Although in other scientific and artistic contexts (e.g. of semiotics) there is a certain boundary between a symbol, sign and metaphor, this text uses the terms as synonyms that complement one another; and the term symbolism is used to define the conception of the use of the symbol.

In architecture of the second half of the 20th century, the discourse of symbolism was mostly associated with an emphasis on the notional component (N. Goodman), phenomenological approaches (Ch. Norberg-Schulz) and semiotics as a science. In the 1960ies, symbolism as one of the qualities of postmodernist architecture was analysed in the works of Robert Venturi, Charles Jencks and Umberto Eco. In contemporary discourse of the architectural theory, the field of symbolism is often supplemented with such terms as "association", "ornament" (decoration of a surface bearing a symbolic meaning), "ideogram" (concept diagram, graphic sign communicating ideas of a building) and "code" (specific, defined system of signs).

In the Lithuanian context, meanings of a symbol in architecture influenced by postmodernism still have been little analysed. Most of attention to meanings of symbols was given by Rimantas Buivydas (1997, 2005a, 2005b), the aspects of iconicity (Bružas 2011) and representation (Linartas 2010) were examined. Nevertheless, the subject has failed to get any broader attention; no focus has been made on symbolism's significant role in architecture of postmodernism. An assumption can be made that this has been because of a relatively short time that has lapsed since the period under discussion, as well as differently perceived meanings of symbols in architecture or underestimation of their significance.

The text does not attempt to define the concept of postmodernism by narrowing it up to the framework of an architectural style with perception of a style as a collection of the characteristic features typical to separate periods of art development, and defining it as unity of expression. The term "postmodernist architecture" or "architecture of postmodernism" is further used to define the architecture influenced by postmodernism as a cultural vector of the epoch in the broadest sense with inclusion or partial embrace of the trends of late modernism, structuralism, post-structuralism, critical regionalism and critical modernism. In chronological sense, objects mentioned in the text were created from the 1960ies and 1970ies up to 2010. The period under discussion only partially overlaps with the usual boundaries of the period of postmodernism, because some aspects of symbolism important to this phenomenon are still relevant in contemporary architecture, which is not necessarily referred to as "postmodernist".
The research focuses on transformation of expression of symbolism in postmodernist architecture by comparing its characteristic features and emphasising the Lithuanian context.

\section{Conception of symbolism and its features in architecture of postmodernism}

Expression of symbolism in buildings is a rather easily identifiable phenomenon in many cities. Symbolism not only reflects the function of buildings, but also emphasises the context and forms of cultural identity. Expression, shapes and meanings of symbolism are closely connected to social, economic and cultural development of society and its transformations. Therefore, symbolic manifestations of architecture may be considered visible expression of politics demonstrating the values, goals and aspirations of the time.

In a general case, a symbol can be understood as an image with a reference, which is specific and also undefined. In the general sense, a symbol can be defined as a sign conveying a certain notion or idea and symbolism, respectively, is an art of thinking in images (Coomaraswamy) (Cirlot 2001).

Philosophy and linguistics suggest their own classifications and taxonomies of symbols. Psychologist and philosopher Erich Fromm defined three major types of symbols: the conventional, the accidental and the universal, stating that only the latter two bear the features of symbolic language. The fundamental system of sign types - of an icon, index and symbol - invented by philosopher and logician Charles Sanders Peirce is known and most broadly applied in the semiotic practice. Regardless of separate attempts to absorb them, the discourse of architectural theory has no strict classification, and the term of symbolism often encompasses icons, metaphors, ideograms and associations. According to Buivydas, the practice of architectural symbolism may be classified into two groups by the level of recognition: "(a) structures by their morphological shape very much alike the general image of the symbol; and (b) image of the symbol is hardly recognisable in the composition of a piece of architecture and estimated as its indirect reflection" (Buivydas 2005a).

While speaking about the role of symbolism in architecture of the 20th century, the influence of postmodernist phenomenon is often distinguished. The second half of the 20th century in art and architecture is usually related to the so-called "crisis of meaning", and the theoretical discourse of postmodernist architecture, in the process of formation at the time, was treated as resistance against neutrality of modernism, "semantic muteness or metaphorical 
silence"(Mallgrave 2010). Besides, according to the contemporary approach, such treatment of modernism - understanding it as functionalism influenced by the International Style - is too narrow, but looking from the postmodern perspective, modernism first of all can be related to functionalist rationality. Such position is illustrated by Venturi's observation that modernism has narrowed the Vitruvian Triad "commodity + firmness + delight" down to "commodity + firmness = delight" (Venturi et al. 1972). In postmodernist architecture, the narrative aspect is emphasised, "not only function, but also fiction" (Klotz 1988), and its main features are named as contextualism, emphasis on local peculiarities, historism, retrospectivism, "postmodern space"1, "difficult whole"2, eclectics and collage, use of metaphors and symbols, use of allusions and ornamentalism.

While discussing the origins of postmodernist phenomenon in architecture, the influence of structuralism, post-structuralism and semiotics, which allowed looking at architecture as culture in general and as collection of symbols, codes and myths, must be distinguished. The works by Eco, Barthes and Greim opened a possibility for semantic, not only sensual-aesthetic way of reading architecture. Semiotics and semiology offered some instruments for "reading" and "decoding" buildings, and formed the discourse of architecture as a language. Influenced by the postmodernist phenomenon, architecture, in its turn, appropriated the language tools and figures, such as metaphors, codes, tropes and syntax (Jencks 1984 (1977)).

It is noteworthy that, although quite broadly spread, the notion of postmodernism has no fixed, unambiguous and well-established definition. This phenomenon is perceived from different perspectives in philosophy, art and literature. Seeking for some generalisation, one can define postmodernism as a cultural dominant (Jameson, Lyotard), or a whole system of all western societies of the 20th century (Hassan). By the second half of the 20th century, the aspect of symbolism in architecture was mostly associated with cognitive, psychological and semiotic researches. According to Venturi, architecture should shift focuses from the modernist approach emphasising space and structure towards the postmodern reading of signs and symbols. Such practice of applying symbols, metaphors and associations was considered to make architecture more acceptable in the social sense and aesthetically enriched. According to architect Kuliešius, "psychological reasoning one's architectural solutions, attempts are being made to avoid or at least soften a possibly neg-

\footnotetext{
1 Terms coined by Jencks and Jameson.

2 Term coined by Venturi.
}

ative society's response to a new piece of architecture" (Kuliešius 1997). In the text, symbolism in postmodern architecture is perceived as a relationship between form, independent façade (coat) and content (function), its expression is considered important for embodying contexts and purposes of buildings and cultural ideas.

Further, the text aims at disclosing the key aspects of symbolist expression in architecture of postmodernism. It analyses examples of Lithuanian architecture and as a context discusses the theoretical discourse of Western architecture. The article examines how symbolism is revealed between figurativeness and abstractness, contingency and intentionality, between forms of buildings and symbolism of surfaces.

\section{Symbolism between abstractness and figurativeness}

Postmodernist criticism emphasised the pragmatic character of modernist architecture, absence of its emotional and symbolic content. "Modern architecture was always abstract (...). We could also say that it became "nonfigurative", because it abolished those "figures" that constituted the basis of the architecture of the past" (Norberg-Schulz 1987). Figurativeness in the theoretical discourse of architecture (NorbergSchulz, Graves) has been understood as enabling associative and anthropomorphic images. However, the difference between modernist and postmodernist architecture cannot be defined by mere denial or acceptance of symbols and ornaments. The initial sources of modernist symbolism - industrial and mechanical images - can be mentioned here. But according to Venturi, they are "dry, empty and boring"; therefore, forms of postmodernist architecture may be named as more open, suggestive, bearing elements of irrationality and its symbolist associations as more pluralistic and multicultural.

Postmodern symbolism as an aspect of communication in architecture is often described as a comparison between architecture and language, aiming to analyse architecture as a language or a linguistic system of signs and symbols. A new trend in contemporary architecture often begins with its declared purpose of "finding a new architectural language". Interpretation of architecture is often compared to a reading process, and architecture itself is understood as an analogue of a language - a certain code able to communicate the author's intentions, or just a peculiar spoken or written language.

The search for a new architectural language with a focus on its symbolic component dates back to the 1950ies. At that time, in Lithuanian architecture influenced by modernism, attempts were made to find 
a theoretical background in modernist strategies of complexity, by forming neutral and often monotonous architectural ensembles. In Soviet times, only the objects of government, politics and culture were visually exceptional buildings (in the aspect of form). Architects, who created such objects, were given more possibilities to search for suggestive forms with the use of associations and looking for specific symbolic reasoning. Symbolism in such buildings was still cautious, fragmentary and indirect; the metaphors of consistency, firmness and monumentality could be applied for their symbolic definition. For example, the division of the stage box of the National Opera and Ballet Theatre (by architect Nijole Bučiūtè, 1974) had to resemble defence towers of a castle or at least hint to "expression of defence architecture or castles" (Riaubiene 1999). Later, the architect repeatedly mentioned the red brickwork character of ancient Lithuanian defence buildings and churches as very close to her aesthetics ${ }^{3}$.

More playful example of reasoning the building morphology could be the Klumpe café (by architect Mikenas, no longer in existence) in Palanga. The title of the café (a clog) was symbolically resembled in the volume of the building. A stylised "wave" of the roof of another object in Palanga - a summer reading hallcafeteria (by architect Čepys, 1968) - could be associated with the sea theme.

Traditional abstract symbolism that encompasses esoteric or religious symbolical meanings still remains relevant in religion buildings. For example: the Church of the Nativity of the Blessed Virgin Mary in Ignalina (by architect Krištapavičius, 1988-1999) bearing the traditional Greek-cross plan; St. Joseph's Seminary

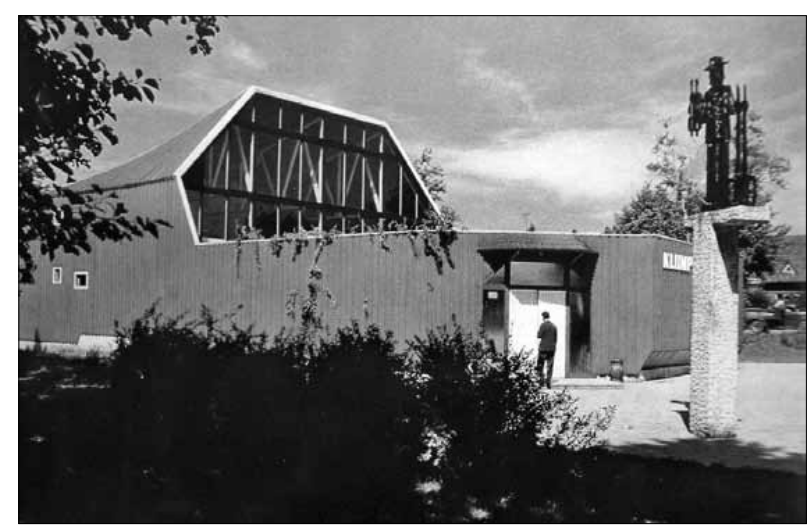

Fig. 1. Pub Klumpé in Palanga, by Architect Mikènas, no longer in existence

\footnotetext{
3 http://www.archfondas.lt/leidiniu/alf-02/indre-ruseckaite-ladamarkejevaite-asmeninis-elenos-nijoles-buciutes-modernizmas\# [cited 12 September 2014].
}

(by architects Šaliamoras and Balkevičius, 1998), in the composition of which the rosary's metaphor can be easily distinguished; and St. Casimir's Church in Klaipeda (by architect Krištapavičius, 1992) with the symbol of an original coat-of-arms of Klaipeda used in the constructions of its tower.

While analysing architecture of the second half of the 20th century, it is worth mentioning that the abstract technological and industrial symbolism related to modernist form-making is replaced by figurative symbols based on anthropomorphism, metaphors of "items from environment" or references to popular culture. Such new manifestations of symbols draw further from involvement of esoteric or religious symbolic meanings.

\section{Architectural symbols in postmodernist architecture}

Another important aspect of symbolism in postmodernist architecture is application of traditional architectural elements, so that buildings could refer to other (historic) buildings. Symbols as conventional signs bearing cultural meaning are used for emphasising representation, reliability or, in other words, embodying "eternal" values. According to Buivydas (1999), in analysis of the historicist trends of the 20th century, at least three prominent rises in these trends can be distinguished. The last wave of historicism in the second half of the 20th century can be related to postmodern turn to the formal systems of historic architecture, at the same time using irony and eclectic match of historical details.

Mykolas Žilinskas Art Gallery in Kaunas (by architects Miliūnas, Kisielius and Juškys, 1981-1989) is considered the most prominent example of postmodernist architecture in Lithuania. Moreover, it can be also regarded as a case of suggestive symbolism quoting historic architecture. Chronologically, the object belongs to the period of late socialism, which could be characterised by a certain ideological liberation and pluralism of artistic expression. The portico at the main entrance and spatial composition of the entire complex, without any doubt, refers to Acropolis in ancient Athens as a cultural sign.

The building of the Hermis Bank in Vilnius (by architects Pempe and Ramunis, 1996) is full of historicist quotes typical to architecture of postmodernism. The general composition of its façade (a column or metaphor of a torch in the centre) and portico with rays (or a metaphor of flames) symbolically resemble another well-known building of the financial institution - the Chamber of Lithuanian Bank in Kaunas (by architect 


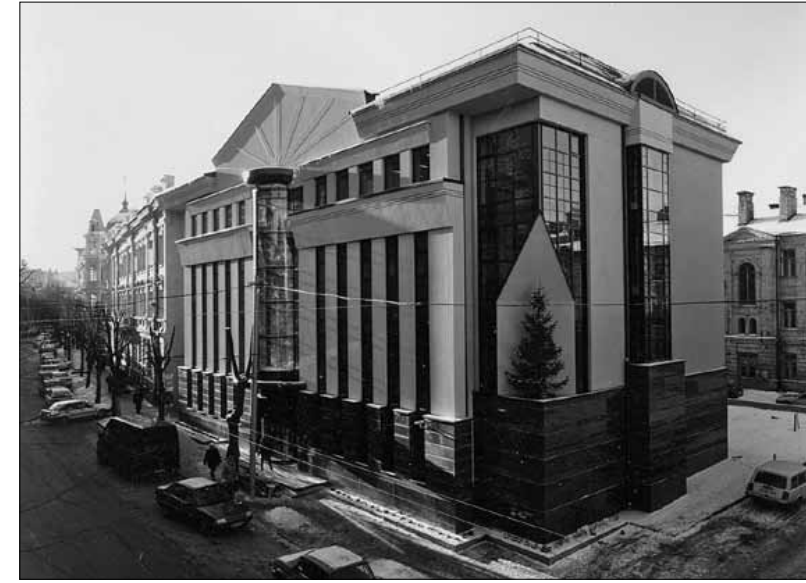

Fig. 2. Hermis Bank in Vilnius, by Architects Pempè and Ramunis, 1996

Songaila, 1924-1927), which is estimated as the most valuable building of the 1920ies in Lithuania (Kančiene 1991). In such a way, one of the first bank buildings constructed after the restoration of Lithuanian independence is a postmodernist interpretation of the central bank building in the interwar Lithuania.

The application of elements of historical styles in postmodernist architecture was aimed at creation of associative forms and construction of entire spatial narratives. An exceptional example of construction of such narrative is the Sundial Square in Šiauliai (by architects Černiauskas, Jurèla, Vyšniūnas and sculptor Kuzma, 1981-1986). The project composition is based on a set of historicist symbols: a classical combination of a sculpture and column, chapel in the proportions of the Parthenon and amphitheatric space. In the semantic sense, this space reconstructs the historical narrative of the city, which was destroyed during the war, with the help of archetypal images (column, way and gate) and in search of specific archetypal language (time, sun and archer).

Archetypal symbols make a significant part of both, Western and Lithuanian postmodernism, which was most popular from the 1970ies up to the 90 ies. The most exclusive example of the local context is catalogues of Lithuanian young architects introducing their design projects made in the 1980ies. Almost all of such works are full of historicist quotes. It is a pity that many of the projects had not been realised due to economic circumstances. The postmodern historicism was different from the earlier manifestations of historicist trends by its rejection of attempts to create a unanimous retrospective style. Rather frequently repeated straightforward symbolism of classical elements had a certain doze of irony; therefore, it should be qualified as pastiche.

\section{Symbolism between contingency and intentionality}

In the 1970ies, exploration of symbolical meanings in architecture started with the use of approaches of structuralist semiotics. For example, in his analysis of architectural communication as the entity of signals and indicators, architecturologist Juan Pablo Bonta emphasised its intentional and unintentional signals. According to Bonta, a symbol in such communicational context can be understood as a signal or pseudo-signal - perceived or unperceived. In other words, he stressed the subjective nature of architectural analysis and architectural perception. Under the influence of postmodernism, modernist architecture was considered to lack a symbolical component or have misleading symbolism. It was expected that semiotics could become a tool not only for research, but also for making architecture.

Because architecture also functions as the means of mass communication (in addition to focus on function dominant in modernist architecture), semiotic and linguist Umberto Eco suggested that architects should be designing for variable primary functions (denotation - utilitarian and functional) and open secondary functions (connotation - symbolic)(Eco 1997). In a similar way, Charles Jencks analysed a major part of discursive and intellectually perceivable symbols by distinguishing the "double coding" concept as important for postmodernist architecture, allowing "to read" an architectural work at least on two levels - elite and folk. This relates to the controversial perception and interpretation of symbols applied by architects. Postmodern architectural symbolism is dichotomous: it is perceived differently by "the concerned minority, usually - other architects" and "the general public"; therefore, its interpretation prospects sometimes may be hard to forecast. Although using public opinion and metaphorical imagination for one's own benefit is typical to postmodernism, quite the opposite may happen: "the general public" may abuse symbolism ruthlessly.

The definition of "a jar"4 widely used in the context of popular speaking about contemporary architecture obviously means symbolic disapproval by a local community. Due to its prolonged hexagonal layout and sharpened silhouette, Hanner office building in Vilnius (by architect Ambrasas, 2000-2002) has been associated with a pencil; but meanwhile, it has had not a single more controversial evaluation, even being com-

4 This "nickname" was used for the hotel reconstruction in the Laisvès Avenue, Kaunas (by architect Juozaitis, 2011); but the term is widely used for other buildings with glazed surfaces. 
pared with a coffin ${ }^{5}$ (according to Jencks, meanings of a symbol depends on the perceiver). "A clear and pure form, it looks like, is very effective, as it makes a certain impact on ordinary town-dwellers - the building has many somewhat vivid nicknames in vernacular speech," - the authors once wrote ${ }^{6}$.

The "K and D Complex" in Klaipeda (by ARCHES studio, 2007) could be mentioned as yet another case of not quite intentional symbolism. In the sense of urbanism, the complex has been planned as a composition of two "torn apart" parts of a solid mass. The authors sought for architectural semantics in the silhouettes of the trade port cranes ${ }^{7}$. But in the public space (probably not without the authors' silent approval) the complex is defined by two letters ostensibly corresponding to the toponyms of "Klaipeda" and "Danë" (the river). In such a way, previously rather ambiguously estimated and blamed for the lack of contextuality, the high-rise object has successfully become site-specific.

From the perspective of semiotic analysis, postmodern coding of architecture could mean that its making, as well as perception and interpretation is always related to an act of coding-decoding; and the
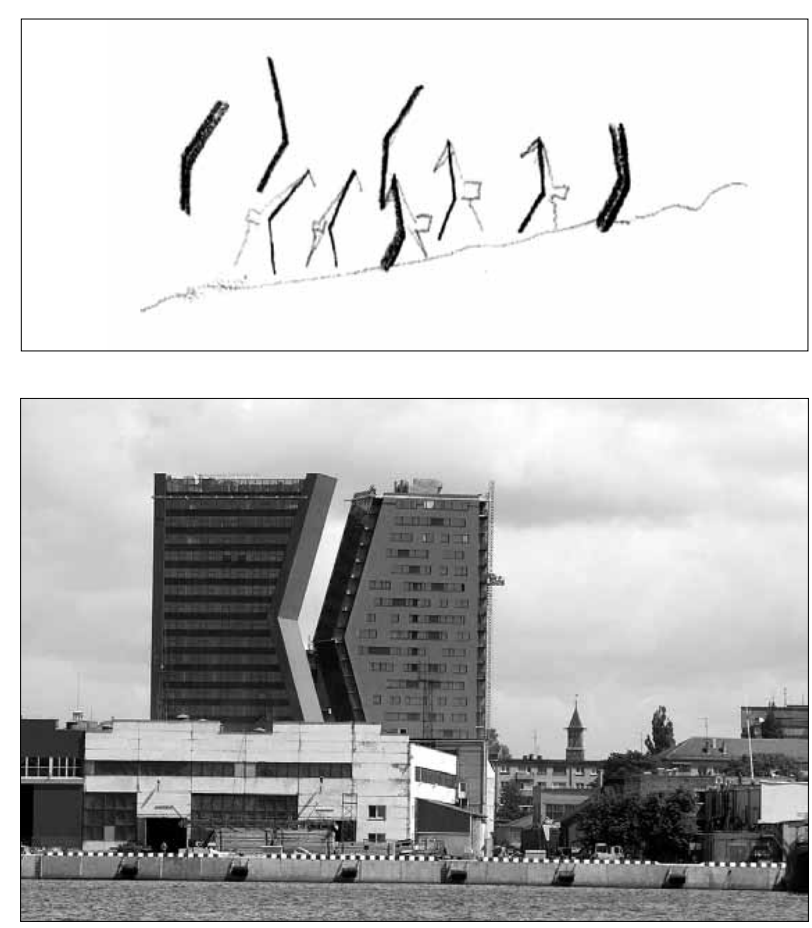

Figs 3 and 4. "K and D Complex" in Klaipeda, a sketch and implemented project, by architectural studio ARCHES, 2007

\footnotetext{
5 http://www.miestai.net/forumas/showthread.php?t=855 [cited 12 September 2014].

6 Compiled by Audrius Ambrasas Architects. 2014. Works 1998-2014. Vilnius: Lapas. 35 p.

7 http://www.arches.lt/portfolio/k-ir-d-kompleksas/ [cited 12 September 2014].
}

coding of architecture is a multilayered, complex, versatile action defined by extremely different levels of perception. Therefore, by stressing out the communicational qualities of architecture, postmodernist symbolism related to expressiveness and figurativeness has become an object of intellectual and populist interpretations. Easily readable meanings of architecture have determined a stronger artistic suggestion, as well as false deciphering.

\section{Symbolism between form and surface}

The book Learning from Las Vegas (Venturi et al. 1972) by architects Venturi, Scott-Brown and Izenour is devoted to symbolist aspect of architecture (in this case, transferred from the popular culture). It is not accidental that the book has a subtitle The Forgotten Symbolism of Architectural Form. In it, such terms as "decorated shed" and "duck" were used for the first time, where "the decorated shed" meant a simple building with figuratively decorated façade (e.g. with ornaments, advertisements) and "the duck" stood for a building with forms giving sense to its function. In other words, in the case of "duck" a direct relationship existed between form and function. In the case of "decorated shed" the relationship between form (surface, in this particular case) and content was not finally defined; a crack appeared between these notions and, thus, a possibility for their mutual contradiction.

A number of contemporary architecture objects (chronologically not necessarily coinciding with the rise of postmodern architecture by the end of the 20th century) is associated with the semantic coding in the metaphorical sense, which represent function through form and surface in a way analysed by Venturi and his colleagues (Mankus 2012).

In Lithuania, the building of Vilnius Branch of the State Social Insurance Fund Board (by architect Gudaitis, 2002) could be used to illustrate postmodern semantisation of form, the main accent of which the hall space shaped as a gigantic funnel - for its client (in most cases - an elderly person) ostensibly refers to a sandglass resembling crumbling sand of life time. The same time metaphor was chosen for the façade composition of Birštonas Branch of the same social insurance institution (by architect Vyšniūnas, 1996) as "a paraphrase of a clock pendulum image" (Grunskis 1997).

The Centre of Ethnocosmology in Moletai Region (architects Krištapavičius and Gudaitis, 2002-08) can also be considered as an example of symbolic application of form. The building was defined as “(...) spa- 


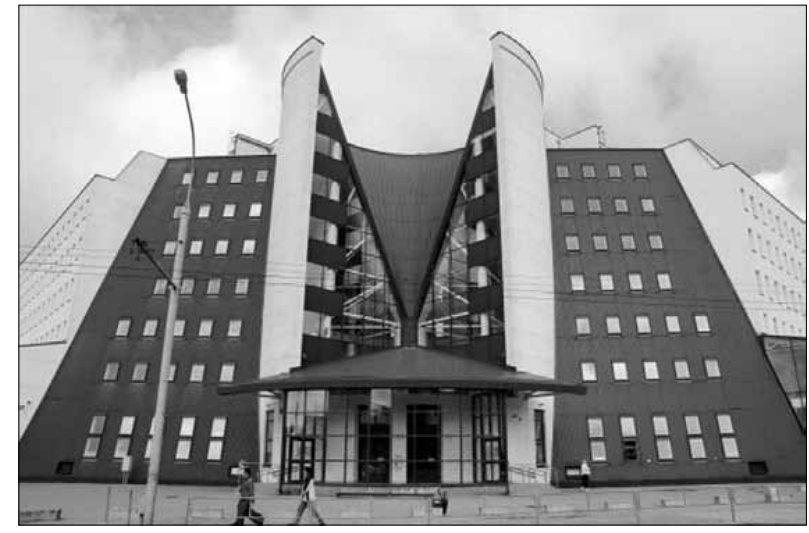

Fig. 5. Building of Vilnius Branch of the State Social Insurance Fund Board in Vilnius, by architects Gudaitis and Baravykas, 2002
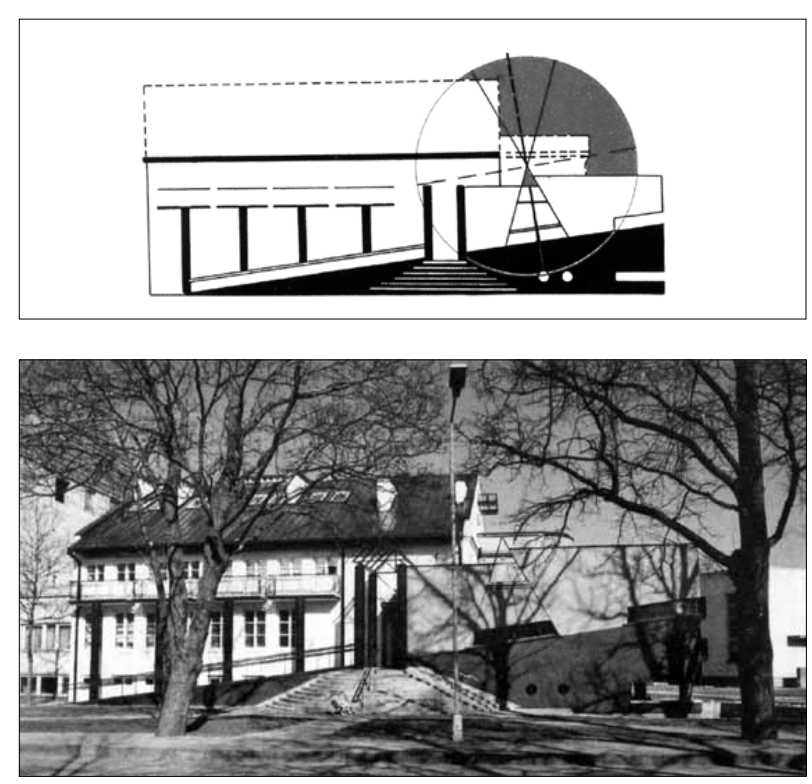

Figs 6 and 7. Social Insurance Branch building in Birštonas, façade compositional structure and implemented project, by architect Vyšniūnas, 1996

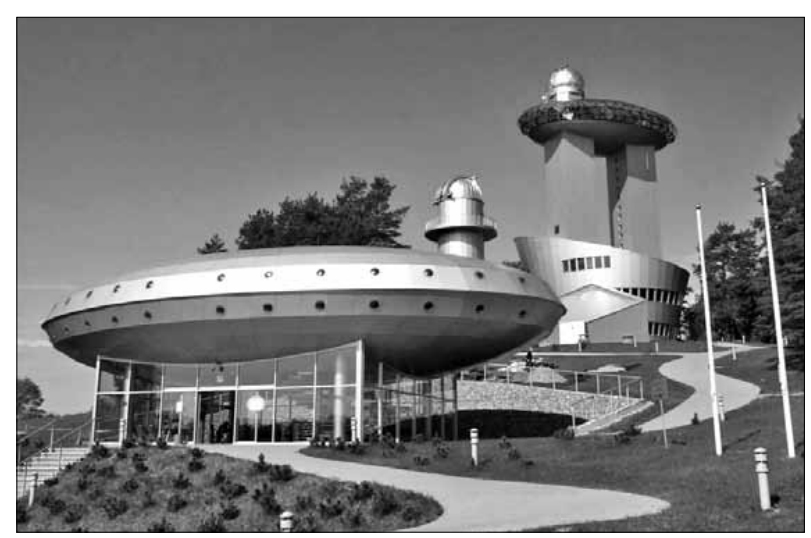

Fig. 8. Lithuanian Museum of Ethnocosmology, in Molètai Region, by architects Krištapavičius and Gudaitis, 2002-08

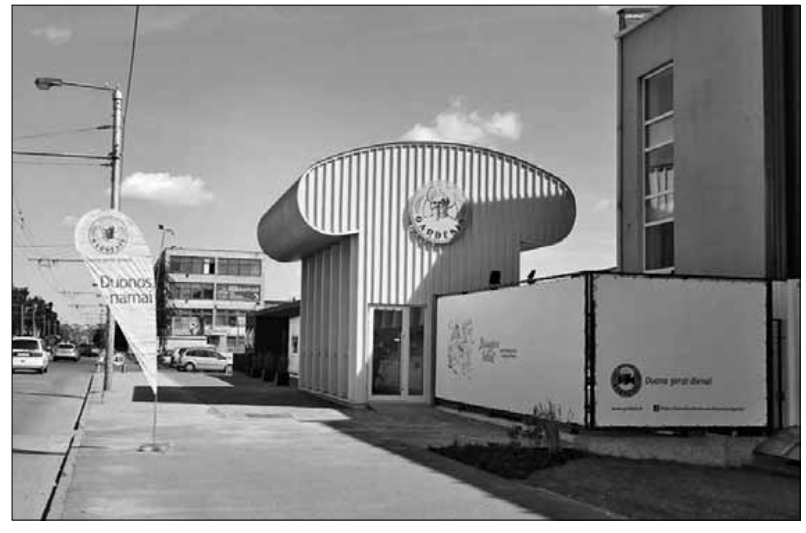

Fig. 9. Gardessis Bakery in Kaunas, by architect Karalius and designer Pranckevičiūtè, 2013

tial sculpture made of absolute forms existing in the Universe forever" (Lietuvos etnokosmologijos... 2005).

An example of more or less literal application of symbolism is Gardesis Bakery in Kaunas (by architect Karalius and designer Pranckevičiūte, 2013), where the form of the building with certain irony in postmodern way refers to a chef's cap or the logotype of the bakery (according to Veturi, it is a "duck" building).

Postmodernist treatment of symbolism allowed for appearance of a contrast between the interior and exterior of buildings. According to the aforementioned Veturi's approach, the exterior of a building (façade) could symbolise independent and contrasting meanings apart from the inside of the building (function). As a result, the surface of the building became an information screen, "artificial" façade with emphasised indirect and more complex relationship between its form and content. A building surface can become an autonomous symbol regardless of its form and internal structure. The reconstructed administration building of Lietuvos Energija AB, in Vilnius (by the architectural studio Vilniaus architektūros studija, 2003) could be provided as an example. On the double façade surface of the building, the visual expression of oscillogram silk-screen printing as the process under exploration (energy in this case) was used. In this particular case, the neutral modernist building under reconstruction was covered with the screen symbolising its function.

This is an interesting phenomenon of contemporary architecture, when both cases of building symbolism described by Veturi can be found in a single object (the result in this particular case should be called "the decorated duck"). Thus, the business centre 1000 in Kaunas (by architect Rimas Adomaitis et al., 2008) can be analysed from the postmodernist approach. In morphological sense, the building symbolises a rolled 
banknote. A glazed façade of the building is decorated with the silk-screen printing of the image of LTL1000 banknote. In such a way, the effect of symbolism is enforced to the maximum.

Symbolism of surface and form is a relatively new construct of postmodern architecture. In Lithuania, it has mostly been observed in the 1990ies up to 2010. As far as a form is concerned, construction of buildings commenced as solid visual formants bearing defined symbolic meanings. A special role was given also to the exterior of the building (façade, surface): in architecture of postmodernism, it is often separated from the internal structure of the object and becomes an independent object itself structuring the building in a symbolic way. A building surface is often treated as information screen broadcasting symbolical meanings of the building.

\section{Some trajectories of symbolism in contemporary architecture}

The examples discussed above show that architecture of postmodernism has refreshed, strengthened and expanded the qualities of symbolist expression. Apart from other things, diagrams, ideograms, codes and analogies should be ascribed to contemporary practical (operational, working) manifestations of symbolism. A need for buildings to be easily recognisable, identifiable and related to some commercial (marketing) narrative, which appeared in times of commodification of culture, is another aspect (e.g. Arfa, Rasu namai, Saules sonata, Vilniaus vartai).

The pursuit of exclusivity forces organisers of the newest architectural competitions to request for the design of symbolic and visual buildings. Bright image, identity, iconicity are the necessary articles of such competition requirements. In part, this is caused by the fact that competitions are usually organised for buildings of exclusive representation functions on exclusive sites. In 2011, the competition for designing the Modern Art Centre in Vilnius was held. The jury made the following commentary on its results: "the Modern Art Centre building has to be a representational sign in panoramas of Vilnius; therefore, a priority was given to design projects, which were not "hidden" underground" 8 . Projects of "non-symbolic" and "non-iconic" buildings (i.e. of moderate expression and less noticeable) were not even evaluated. The international competition for Guggenheim Museum in Vilnius (2008) should be considered one of the most prominent cases of recent postmodernist development. It was not accidental that organisers of

\footnotetext{
8 http://www.architektusajunga.lt/naujienos/mmc-konkursas [cited 12 September 2014].
}

the competition invited architects known for their individualised expression and recognisable signature. The winner project - the offer by famous Zaha Hadid - could be estimated as (imaginary) symbol signifying the cultural wellbeing of Vilnius City and also as a postmodernist simulacrum trespassing the logic of economical experience.

Another case is the competition for designing the Lithuanian pavilion at the international Expo 2015 exhibition in Milan held in 2014. It is obvious that in such global exhibitions no space is left for the national, ethnic and constructive authenticity; therefore, in selecting the exposition, a crucial role is played by symbolism as the value added to architecture. "The prestige game is won by the country that tells best about what it does, independently of what it actually does", Umberto Eco wrote about the international exhibition in 1967 (Eco 1997). Nowadays, it is still the same: the main selection criterion in a competition for such exhibition is secondary or, according to Eco, a connotation - symbolic architectural functions developed to the maximum.

By the end of the 20th - in the beginning of the 21 st century, a trend related to postmodernism started emerging: a symbol often drifted away from the object it signifies and became hardly recognisable, or, according to Baudrillard, a sign was dissociated from its referent and pure simulation was settled. As architect Audrius Ambrasas, the author of a few initial high-rise buildings in Lithuania, has put it (in this case, he was speaking about analogous buildings in the Arabian countries): "neither the tasks to create the interior space, nor the aims to design the external spaces are formulated for such buildings (high-rise buildings, the author's remark). It could possibly be considered as the design of very large items" (Audrius Ambrasas Architects 2014).

A symbol remains significant in contemporary architecture for its meanings and qualities. Spaces and towns can be recognised by their visual and meaningful symbols. Symbols are mostly manifested in cities, the entirety of symbols forms the identity of spaces. Moreover, in contemporary global world, symbol and symbolism in architecture becomes a tool for public relations, visual manifestation of economic wellbeing and cultural diversity. Symbolism in architecture turns not only toward buildings, but also toward a city and its entire space. Symbolical expression (linguistic, musical, artistic, architectural, etc.) is required by collective identities (a nation, society, institution) to express itself and maintain the status. General expression of symbolism in postmodernist and most recent architecture is not only rendered by architects' activities, but also becomes a part of strategies employed by different groups of society and power structures. 


\section{Conclusions}

The tradition of symbolism in architecture preconditioned the search for meanings, enriched artistic expression and suggestibility. In architecture of postmodernism, this trend gained new qualities resulting in contradictions of form and polysemy of content.

Expression of postmodernism in the Lithuanian context can be defined as a complex combination of western aspirations and local possibilities, and symbolism - as one of the most important (but not a single one) features of postmodernism. Complexity that came from the West (freedom of choice, aesthetical pluralism) determined the expression of symbolism as a response to the cultural context, search for identity and possibilities provided by subjectivity of artistic approach. A reflection of western culture of diversity in the Soviet context was partially defined as resistance against functionalism.

Manifestations of symbolism related to postmodernism in Lithuanian architecture date back to the 1970ies up to 2010. Regardless of all dramatic changes of the socio-cultural situation in the 1990ies, the tradition of symbolism characterised by interpretations of historical forms, expression of forms and surfaces has remained with some minor transformations.

Architecture of postmodernism has drawn new guidelines of symbols and signs: starting with esoteric and elite towards daily and natural. It is also noteworthy that the period of postmodernism refreshed many ways of expression suppressed by modernism; therefore, a question how much these ways are new and unique is still relevant. A possible answer to it could be the postmodernism's ability to match different ways of expression by providing new combinations.

Postmodernist symbolism in architecture was based on semantic creation of meanings. Its expression encompassed cautious abstractness and straightforward figurativeness, symbolism of historical forms and elements, morphology of buildings and their surface modelling; symbols have become literal or very remote from their sources. It is noteworthy that by the end of the 1990ies, the period related to postmodernism, the trends of historical symbolism becoming formal and accidentally entrenched in Lithuanian architecture. Meanwhile, modelling of symbolic forms and surfaces became a guarantee for successful geographic and cultural contextualisation. Symbolism as non-verbal communication and postmodern use of clearly perceivable and readable signs and symbols in architecture allowed communicating with extremely wide part of the society. Postmodern symbols used in architecture have become signs of the use of culture and aesthetics. Symbolist aspects in architecture allowed embodying the images of socium's economic and cultural wellbeing - not only by restoring the existing, but also creating imaginary ones.

\section{References}

Audrius Ambrasas Architects. 2014. Works 1998-2014. Vilnius: Lapas. $35 \mathrm{p}$.

Bružas, A. 2011. Šiuolaikinès architektūros orientyrai - ikoniški pastatai hierarchinès klasifikacijos sistemoje, Mokslas Lietuvos ateitis 3(3): 109-114.

Buivydas, R. 1997. Architektūros kalba ir simbolizmas, Archiforma 4: 74-80.

Buivydas, R. 1999. XX a. architektūra: istorizmas, Archiforma 1: 69-74.

Buivydas, R. 2005a. Simbolis architektūroje: nuo individualumo iki universalumo, Urbanistika ir architektūra XXIX(1 priedas): $42-49$.

Buivydas, R. 2005b. Ezoterinis simboliu pasaulis. Vilnius: Spaudos kontroles valdyba.

Cirlot, J. E. 2001. Dictionary of symbols. London: Routledge.

Grunskis, T. 1997. Birštono Genius loci, Archiforma 1: 55-60.

Jencks, Ch. A. 1984 (1977). The language of post-modern architecture. London: Academy Editions.

Klotz, H. 1988. The history of postmodern architecture. Cambridge, Mass./London: MIT Press.

Kančienè, J. 1991. Lietuvos bankas, iš Kauno architektūra.

Kuliešius, V. 1997. Asociacijų reikšmė architekto kūrybai, Archiforma 3: 41-43.

Eco, U. 1997. How an exposition exposes itself, in N. Leach (Ed.). Rethinking architecture, a reader in cultural theory. Routledge.

Lietuvos etnokosmologijos muziejaus rekonstrukcija (straipsnis parengtas pagal muziejaus direktoriaus G. Kakaro medžiagą). 2005. Archiforma 1(2): 49-51.

Linartas, D. 2010. Esminès reprezentacinių siekių igyvendinimo architektūros konkursuose formos ir tendencijos, Mokslas - Lietuvos ateitis 2(3): 24-30.

Mallgrave, H. F. 2010. The architect's brain, neuroscience, creativity, and architecture. Wiley-Blackwell.

Mankus, M. 2012. Metafora kaip postmodernizmo architektūros raiškos priemonè. Lietuvos atvejis, Urbanistika ir architektūra 36(3): 170-180.

Norberg-Schulz, Ch. 1987. On the way to figurative architecture, Places 4(1): 18.

Riaubienè, E. 1999. Elena Nijolè Bučiūtè: architektūra - tai praktine paskirtis ir meninè prigimtis, Archiforma 4: 46.

Venturi, R.; Scott Brown, D.; Izenour, S. 1972. Learning from Las Vegas. Cambridge MA: MIT Press.

\section{MARTYNAS MANKUS}

PhD student at the Department of Architectural Fundamentals and Theory, Vilnius Gediminas Technical University,

Pylimo g. 29/Traku g. 1, 01132, Vilnius, Lithuania,

El.paštas: martynas.mankus@gmail.com.

Research interests: history and theory of modern and contemporary architecture, methods of architectural research. 